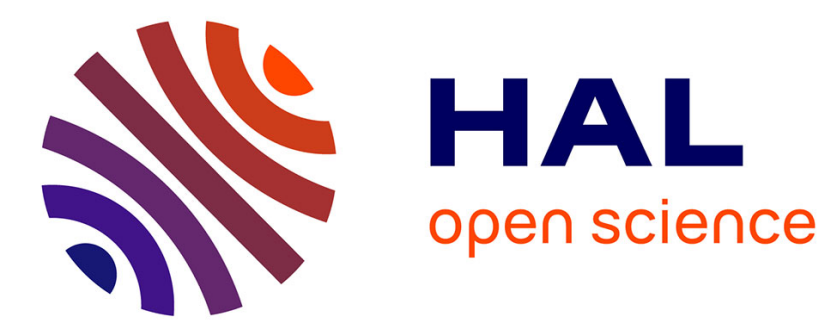

\title{
Popular mobilisations in Lebanon: from anti-system to sectarian claims
}

Daniel Meier

\section{To cite this version:}

Daniel Meier. Popular mobilisations in Lebanon: from anti-system to sectarian claims. Democracy and Security, 2015, 11 (2), pp.176-189. 10.1080/17419166.2015.1036238 . halshs-01337707

\section{HAL Id: halshs-01337707 https://shs.hal.science/halshs-01337707}

Submitted on 28 Jun 2016

HAL is a multi-disciplinary open access archive for the deposit and dissemination of scientific research documents, whether they are published or not. The documents may come from teaching and research institutions in France or abroad, or from public or private research centers.
L'archive ouverte pluridisciplinaire $\mathbf{H A L}$, est destinée au dépôt et à la diffusion de documents scientifiques de niveau recherche, publiés ou non, émanant des établissements d'enseignement et de recherche français ou étrangers, des laboratoires publics ou privés. 


\section{Popular mobilisations in Lebanon: from anti-system to sectarian claims}

Daniel Meier (CNRS-Pacte, Grenoble)

\section{Abstract}

In Lebanon, the Arab uprising is often analyzed through the lens of the side effects the Syrian uprising had on the country thanks to massive refugees influx and the involvement of Sunni and Shia Lebanese in Syria's battleground. In fact, popular mobilizations happened prior and during the current crisis as two different type of effects of the Arab uprisings at large. First, in late 2010 emerged an anti-sectarian movement that brought up an anti-system claim in line with other Arab social movements targeting authoritarian regimes and corruption. Second, the Sunni radical mobilization that started in Saida in 2011 around the popular Imam Sheikh Assir, gathered resentments toward the Shia leading party Hizbullah as involved alongside the Syrian regime and surprisingly adopting an active minority mobilization strategy. Both movement conducted demonstrations of different type (from classic march to on roads sit-in) starting from a completely opposite perspective and in a very different environment: when the anti-sectarian mobilization faded, the sectarian one rose. This paper will try to address the historical process of both mobilizations and assess their differences in light of several mobilization theories. It intends to raise questions about the type of actors involved, their discourses and justifications, and the contextual local and political environments.

Keywords: Lebanon, popular mobilization, anti-sectarian movement, Salafist movement, discourses and justifications

A gap prevailed for a long time between the study of societies in the Middle East through anthropology or political science research, and through the social movement theories (SMT). This area of the world was largely left on the sidelines of the debate on SMT and remained trapped within neo-Orientalist readings on Islamist movements. However, since the new century, studies using SMT theoretical background in Middle Eastern countries have become more numerous and have been evaluated positively ${ }^{1}$. While English publications tend to remain more focused on general analyses like Lynch ${ }^{2}$ or Tripp $^{3}$, fruitful works on social movements and popular uprisings in several Arab 
countries have been recently published in edited books by French researchers like Allal and Pierret ${ }^{4}$ or Bonnefoy and Catusse ${ }^{5}$. In Lebanon, the study of social movements through the prism of the civil society regained interest in the post-civil war era during the 1990s and reached a more theorised form by early 2000 with several milestones like Kingston ${ }^{6}$ and Favier ${ }^{7}$ and later on Karam ${ }^{8}$. But considering what did or did not happen in Lebanon regarding the uprising momentum, little has been said on local social movements who took the street or layed claims. And no clear links have been made between the context of the Syrian uprising and social mobilisations among sects except for security and political assessments 9 .

Lebanon is a country that remained at the margin of the Arab uprising process after the mass protests of 2005 that set the tone of a society mobilisation for its dignity and freedom but also for its fidelity to sectarian patrons ${ }^{10}$. However, the Syrian uprisings impacted deeply within the Lebanese political game because of the previous old and deep links that existed between the Lebanese ruling class and the Syrian regime, particularly in the post-civil war era. I have shown elsewhere how the two main political parties in the opposite coalition, Hizbullah and the Future Movement, imported the Syrian fault line between Sunnis and Alawites - largely built by the Syrian power to serve its mobilisation against "Islamist threat" - for their own political interest ${ }^{11}$. Within this context, I am going to investigate two Lebanese social movements which have lately appeared on the political scene: the Anti-Sectarian Movement (ASM) in the aftermath of the initial uprising in Tunisia and Egypt and the Movement initiated by Sheikh Ahmad al-'Asîr that took shape after the beginning of the Syrian uprising. They refer to two distinct segments of the Lebanese population - the secular vs the Sunnis militants - in two different locations - Beirut vs Saida - and at two different periods of time, respectively late 2010/early 2011 and late 2011/mid-2013.

The focus on these two mobilisations will not be done through the lens of "the civil society" concept firstly as it appears to be based on a western civil society conception that stays far from authoritarian regime contexts. I have rather chosen to rely on tools provided by the contemporary social movement theory, inspired by McAdam, Tarrow and Tilly's perspective in Dynamics of Contention ${ }^{12}$, which proposes a relational perspective with a focus on interpersonal networks as well as an emphasis on a 
diachronic and contextualised analysis of mobilisation mechanisms. So my main goal will be to systematise the comparison between the anti-sectarian movement and the Sheikh al-'Asîr movement with corresponding tools of the abovementioned theoretical framework. In this perspective, one can identify three main directions for a comparative investigation: the context, the networks and the practices of contentious movements ${ }^{13}$. The first intends to underscore the local context as a significant variable in order to provide precise descriptions of matrices of constraints and resources surrounding the two movements, including perceptions. The second will focus on social settings and informal networks in contention that encompass pre-existing social movement organisations. This does not mean believing in individual rationality - be it based on material or culturalistic factors - but instead staying focused on the social aspect of power. The third consists in investigating what people do when they protest, which means the study of the repertoire of collective action. This dimension clearly links the action to its context; the concept of repertoire also "assumes a universe of shared meaning, prior to mobilization"14, like symbols, stories, rituals, etc, all highlighting a selfdefinition of contentious actors as well as movements' identity regarding their vocabulary, behaviours, perceptions and actions/strategy within the political field.

In this paper, I will contend that despite their opposing postures on values and opposite sociological components, these two movements belong to the same momentum of the Arab uprising regarding its specific impact on the Lebanese socio-political environment. In other words the two social movements under scrutiny can reveal in their functioning how the crisis, and the Syrian uprising in particular, created an environment that proved conducive for each of them at two different periods of time. This work is based on several fieldwork periods in Lebanon since early 2011, in collaboration with Giacomo Galeno for the research on the anti-sectarian movement. It is based on direct observation, interviews with militants, researchers, officials and other Lebanese actors in NGOs. It also relies on grey literature like flyers distributed during protests, sit-in or marches and other observations during meetings and outside meeting tents. Finally, I refer to newspapers and Internet references for political speeches and statements and other secondary sources like academic papers related to both movements.

\section{Contexts of emergence and of opinion}


When considering the emergence of the two movements, a striking difference appears regarding the context and how actors formulate their opinions within it. For ASM militants, the interviews conducted and more obviously their main slogan "al-shaab yourid isqat al-nizam al-ta'ifi" ("The people wants the fall of the confessional regime") which mimic the original "al-shaab yourid isqat al-nizam" ("The people wants the fall of the regime") already famous in Tunisia and Egypt show quite clearly the will to link and affiliate their mobilisation within the regional mobilisation against authoritarian powers. Moreover, it is rather clear that events in the Maghreb - the quick fall of Tunisia's Ben Ali regime followed by Egypt's Moubarak speeded up the formation and the mobilisation of the movement in Beirut. Its "anti-sectarian" brand stemmed from an older claim that has its own history in Lebanon. It referred to the civil marriage claim that started already in the 1950s as the Lebanese Constitution, in its article 95, made it compulsory for every Lebanese citizen to belong to one of the nineteen recognised sectarian communities; in other words, it is simply not possible to get married today in a civilian way only. With this Constitution article, the Lebanese Parliament acknowledged the power of sects on personal status and left its prerogatives on that matter to the religious authorities of each sectarian community., The debate commenced anew with the Taïf Agreement, in 1989, which put an end to the civil war and shaped the new Constitution of the Second Republic as it suggested to "de-communalise" the political system, a task Elias Hraoui, the first President of the Republic, tried to undertake in 1995 but failed to complete when sectarian patrons opposed to the creation of a civil status $^{15}$. This is the perspective of the ASM main claim within the general claim of Arab uprisings targeting authoritarian regimes. Lebanese militants explain that contrary to other Arab countries, Lebanon has not one but several authoritarian leaders to fight, within each community. So, for ASM, one can follow Allal and Pierret ${ }^{16}$ and talk about a spreading effect, in Lebanon, of this "revolutionary momentum". The external factors are rooted in the uprising claims for more social justice, dignity and democracy while the local context of ASM mobilisation is marked by an absence of any political change from the perspective of the rulers as if what was happening in other countries was identified with a disease or a virus that may not reach Lebanon ${ }^{17}$. At that moment, the Syrian uprising did not yet started and only became salient in the public space by the summer 2011 when ASM faded away. 
For its part, the movement initiated by Sheikh Ahmad al-'Asîr emerged late 2011 as a local radical religious group of a small mosque in a suburb of Saida in a context of Salafi clerics mobilisation supporting the Syrian uprising ${ }^{18}$. In his speeches and preaches, Sheikh al-'Asîr referred from the beginning to the Syrian uprising as a threat to the honour of the Sunni community. So contrary to the ASM movement, al-'Asîr mobilisation was not inspired by the overthrow of authoritarian regimes. Instead, he provided a sectarian reading of the struggle in Syria and immediately made a link with the disregard of "Syrian-Iranian tutelage over Lebanon" towards Sunni people. This is a sort of revamping of the initial non-sectarian call of each Arab uprising. In sum, external factors for al-'Asîr's mobilisation appeared limited to the Syrian uprising as it was understood as a fight against the Sunnis. And the context for the main process of successful mobilisation did occur during the year 2012 when the Miqati government set up its "dissociation policy" towards Syrian uprising in order not to be affected by the Syrian turmoil but in reality to seem neutral and continue to act as an ally of the Syrian regime ${ }^{19}$.

Both movements seemed to have internal agendas. The ASM one was focused on a regime change by implementing a secular Republic while al-'Asîr movement was devoted to the promotion of the Sunni community by denouncing the powerful Shi'i-led Hizbullah and supporting the fall of the Assad regime in Damascus. To do so, the two movements did not have the same constraints and assets to act on the political scene. When it emerged, ASM was a civil society movement with no links to institutional politics because of its radical anti-system posture. In the meantime, the previous experience of some of its members alongside with the Laique Pride eased the formation of the core group around some radical ideas and ideals. The movement did not directly use the fact that the Taï Agreements raised the question of the abolition of sectarianism in politics. But the debate was already well known within the society and ASM could rely on that to expect to gather a social dissent towards the Lebanese political actors.

For its part, al-'Asîr movement was in a weak position to start its mobilisation as Ahmad al-'Asîr was not a recognised cleric and was preaching in a small mosque located in a suburb of Saida. Moreover, his previous affiliation with Jamaa al-Tabligh, a quietist 
religious movement that openly avoided any statement that could lead to a conflict, was not really conducive to the gathering of radical partisans. In the meantime, among the opportunities that served al-'Asîr was the length of his investment in that Mosque and his strategic opportunism the moment the uprising started in Syria in sidelining with Hariri's Future Movement. His activism and his reputation as a Salafi figure spread during the Ramadan (summer 2011) and provided al-'Asîr with an audience. The economic situation of Saida as a pauperised city suffering from a lack of investment granted his movement with followers among the poor or disappointed Sunni fringe of that Sunni town. Hizbullah was then useful for al-'Asîr as it was progressively identified as the evil Shiite group that could be blamed for their disempowerment and for threatening the Sunni in the region and in Lebanon. The May 2008 events - during which Hizbullah took the street by force in West Beirut to constrain the Sunni leaders to pull back on a political decision - were reminded several times as a wound to Sunni honour that needed to be repaired. In sum, the internal context of emergence of the movement of Sheikh al-'Asîr reveals the importance of the conflict for the growth of its reputation, the necessity of identifying a local antagonist figure, Hizbullah, threatening the community to legitimise the struggle for the Sunni pride.

\section{Networks for mobilisations}

In the perspective of "looking for the weapon of the weak" 20 , I am now going to consider the social context of the networks and the power relations they embody in both case studies, assessing the conditions that render those mobilisations possible. The antisectarian movement founded support and resources in the network of civil society actors stemming from militant groups of the 1990s that all sustained an ideal of secular society for Lebanon. These groups, associations, and NGOs, brought their expertise and skills built during years and through past experience into the ASM. There are several generations of actors within it and no linear history, but at least one can find a starting point in 2010 with the first "Laique Pride" movement. This first gathering originated on Facebook talks among activists to promote a secular change in Lebanon, focusing on a claim for a secular law for personal status including marriages. Many among these people still had a militancy network and were involved in promoting, in a way or another, secularism in Lebanon. Groups or NGOs which responded to the call for a 
"Laique Pride" were, among others, l' "Union des Jeunes Libanais Démocratiques," "le Mouvement de la société civile" linked to the "Mouvement Social" created in 2001 by Mgr. Gregoire Haddad, the Secular Club of AUB, and "le Rassemblement populaire pour la laïcité". When the meeting of this Laique Pride occurred on 25 April 2010, gathering roughly 5000 participants, it created hope for the following up and re-opening of the debate among a vivid civil society. Later on, an informal meeting took place, under the name of "Rencontre séculière" that aimed at coordinating efforts to shape an antisectarian movement of broader size.

The main strategy of the organisers was to target the confessional system through a specific problematic like the reform of the electoral law, and the law for a civil personal status. The movement also aimed at targeting the system of governance in itself by voicing their interest in the promotion of social justice and of the struggle against corruption. After the flight of Ben Ali from Tunisia and the breakdown of Mubarak in Egypt on 11 February 2011, the Laique Pride gave a press conference on 20 February to announce the 2011 edition of its demonstration. During the press conference, a split appeared as several members expressed their will to expand their claims, taking into consideration the regional context of the Arab uprising. The "Rencontre séculière" then launched a call on social networks to gather on Sunday 27 February in order to claim for the abolition of the sectarian system.

While no long-term strategy was initially taken, this newly born Anti-Sectarian Movement succeeded in gathering large numbers of participants in several cities in Lebanon. Its short-term and broad strategy as an independent movement was to bet on a full-scale national mobilisation in every region of the country. After the initial demonstration on 27 February, the ASM succeeded in gathering four other demonstrations in four other locations, with great success in Beirut when approximately 20,000 people marched from East to West Beirut on 20 March 2011. The strength of this gathering also came from its self-perception as a silent majority becoming defiant towards traditional political parties and expressing the will to change the sectarian system (al-nizâm al-taifi) for social, political and judicial purposes. 
The social context in Saida in 2011, when Sheikh al-'Asîr started his mobilisation, is marked by the polarisation of the Lebanese political forces towards the Syrian crisis, namely Al-Mustaqbal facing 8-March local ally Mustapha Saad and Hizbullah militants in the city and its surroundings. The socioeconomic situation in Saida was already critical and behind the touristic reshaping of roads and streets in the old city, a process of pauperisation affected the majority of the local inhabitants, mostly Sunni, because of the lack of investments which together created a slow disenfranchisement of the population towards national concerns except for its local Sunni constituency. This sectarian affiliation soon became the only common identity for inhabitants who perceived themselves as abandoned by the central power and instrumentalised by the main political parties. Sheikh al-'Asîr found a fertile ground there for his mobilisation based on resentment and a feeling of marginalisation. He was also able to capitalise on a frustration towards the Shiites because of the political fight of early May 2008 that saw a confrontation between Hizbullah and the Siniora-led 14 March government. During these boxing days, Hizbullah's militiamen and allies sealed off West Beirut, stranded Walid Joumblatt and Saad Hariri ${ }^{21}$ in their houses, thus shedding a crude light on the Future Movement's impotence towards the Shi'i movement. In the following years, several attacks targeted senior security officers and political leaders, all of them stemming from the Sunni community. Sheikh al-'Asîr was then able to play on sectarian honour, transforming a political weakness into a sectarian threat. This link between sects-politics-honour was repeated in Friday preaches.

“We won't accept this abject (haqīra) Syrian-Iranian tutelage (over Lebanon) ! [...] Enough contempt for the Sunnis! Enough contempt for their blood, their security and the honour of their wives! $»^{22}$

Manufacturing a sectarian reading of the situation Al-'Asîr was able to mobilise anger and dissatisfaction, blaming the pro-Syrian partisans identified with the Shia community. To illustrate this strategy of sectarianisation of the dissent toward the Shia, the religious dispute with Muhammad Yazbek, a top rank leader of the Party of God, is a good example as it also raised concern with Hizbullah itself ${ }^{23}$. Sheikh al-'Asîr started a religious dispute after a Yazbek speech allegedly "insulted" Aisha, the mother of the Prophet, and thus positioned himself as the defender of the Sunni community. This 
sensitive matter in a pluri-sectarian society granted him with a full media attention and allowed him to reach a larger Sunni constituency, close to Al-Mustaqbal, bridging the religious with the political dissent when al-'Asîr mentioned the Hizbullah weaponry, a classical topic of the 14 March coalition. The strength of this posture lay in the powerful position of his Shi'i foe in the political game on the one hand and on the other in the brutality of the repression the Syrian population, mainly Sunnis, suffered from the alAsad regime. This power, labelled as Alawite because of its sectarian affiliation, has been affiliated with Shi'i belief since the onset of the Syrian uprising in Salafi circles, thus showing an evil alliance between the two minorities in Islam, the Alawites and the Shia. This "natural" explanation of their political alliance helped Sheikh al-'Asîr to identify Hizbullah as the internal threat for the Sunnis of Lebanon and so positioned this community as a victim and possibly as a gatekeeper of the Islamic orthodoxy toward the deviant ones ${ }^{24}$.

In sum, the networks for mobilisation are totally different as they rely on two distinct type of attitude toward the social environment. When ASM tried to politicized the sectarian issue at the core of the Lebanese political system, Sheikh al-'Asîr tried to do the exact opposite in sectarianising the political dissent with Hizbullah, using each opportunity to remind its constituency of the threat the Shia can be for the Sunnis. The ideological networks on which ASM built its mobilisation and its identity is thus in stark contrast with al-'Asîr sectarian mobilisation.

\section{Repertoires, identities and the vocabulary of mobilisation}

Investigating contentious practices can be made using Tilly's notion of "repertoire of collective action" as it allows the observer to look at detailed aspects of a protest, modes of action, constraints and resources of protesters in action, their cohesion and their selfdefinition. By providing an in-depth look at "how" mobilisations are organised, the conceptual category of "repertoire" offers means to reflect on the identity of political causes and on the vocabulary of motives people are using (elitist/populist, oppositional/radical). 
As seen above, the ASM protesters decided to organise several marches and demonstrations in different locations in the main cities of Lebanon. They faced a lot of resistance among the State bureaucracy as no political forces were supporting them. This meant that they faced the arbitrariness of the Ministry of Interior that is granting such permits and showed a strong will to be heard. This high motivation of the demonstrators can explain the success they finally reached when demonstrations culminated with the approximately 20,000 people gathering in Beirut in a march that ran from Sassine-East Beirut, a Christian hotspot to Sanayeh-West Beirut in Muslim suburbs, in front of the Ministry of Interior. Two days prior to this mass demonstration in downtown Beirut on 20 March 2011, a group of activists affiliated with ASM organised a sit-in with tents at Riad al-Solh Square - close to the Parliament and the financial district of Beirut - to protest the government's inaction in adopting a civil marriage law ${ }^{25}$. Banners were reading "Freedom of Belief, Freedom of Thought", a claim also heard in other ASM marches. The same day, two other rallies took place in Nabatiyeh and Baalbek with the main slogan chanted. In the organisers' view, implementing legislation for a secular State that would change the power establishment, would create a "domino effect," undermining the impact of sectarianism on the society and therefore on the client-patron system, a corrupt and poor governance of public goods responsible for a lack of social justice. These demonstrations were also a great success regarding the diversity of people they brought together: Lebanese as well as Palestinians, women and men from various age categories and from different sects too. Regarding the ideological orientation of those marches, one can note the presence of several civil society associations and advocacy NGOs as well as few leftist and secularist intellectuals, few religious personalities Christians as well as Muslims, and some leftist political parties.

Regarding its members, ASM can be described as a mainly elitist and radical movement. When asked to comment on their experience during that spring of mobilisation, ASM activists expressed discomfort regarding what they felt as two main problems linked to the cohesion of the group. Firstly, there was a massive influx of new young members bringing pluralistic points of views, because of the social network call for meetings, owing to some of them. This led to the constitution of two options/visions for the future of ASM mobilisations: one could be described as the reformist line, calling for 
opportunistic alliances with several political parties, and the second option could be seen as the revolutionary line, with a radical position as it refused any kind of collaboration in order to avoid any sort of "recuperation" of the social movement giving popular legitimacy to any political party. Another problem that ASM faced was due to political interferences as SSNP and Amal tried to take control of the movement, sometimes using threat. Such problems aggravated the moment several members expressed their desire to show solidarity with the Syrian protesters. One can note that some members then chose to leave the ASM in such a troubled environment thus showing the limit of the political scope allowed by main political parties and its effect on the mobilisation when people opt-out.

The opportunistic attitude of the ruling class towards the ASM movement was twofold: either to use their claims in order to bring a new asset in the political debate (Joumblatt, Berri) or to try to integrate the movement in a political campaign (Hariri), all positions having a political agenda and none of them really wanting to consider the movement as a social force in itself. Several segments of this ASM group re-launched a new mobilisation for social justice that gathered 400 people on 27 February 2012, expecting to reawake the anti-sectarian movement one year after the initial gathering ${ }^{26}$. Some others took part in the annual Laique Pride which resulted in a lukewarm success that year, gathering only 3000 people for a march on $6 \mathrm{May}^{27}$. And finally, another group emerging from ASM chose to mobilise in a Civil Campaign for Electoral Reform on 13 May and organised a march towards the Parliament, asking for a new electoral law based on proportionality and decreasing the voting age to $18^{28}$.

Contrary to the collective dimension of the ASM movement, the Salafist movement of Sheikh al-'Asîr was intrinsically linked to his person. In this sense, his movement was more familiar within the Lebanese political realm as the personalisation of power can be identified as one main trend in politics ${ }^{29}$. Sheikh al-'Asîr became known as a salafist between 2000 and 2003 as it seems clear that he followed the doctrinal principles of salafism $^{30}$. In the meantime, al-'Asîr, like other sheikhs, wanted to promote an image of himself as a non-sectarian figure to show his moderation in the media outlets more than trying to gather a larger spectrum than the Sunni citizens he primarily targeted. 
Nevertheless, the populist and radical dimensions of al-'Asîr movement can be highlight by examining the steps and repertoire of mobilisation adopted.

During a first period of time, al-'Asîr organised demonstrations in support of the Syrian uprisings or against the Hizbullah weapons, clearly investing the polarisation of the political spectrum towards the Syrian uprising. Mobilising through social medias, the Sheikh al-'Asîr movement grew in number and tended to radicalise its action by organizing a sit-in in Saida during one month and a half, blocking a main road and so continuing its entrism strategy, raising the flag of the Sunni community threatened by weapons of Hizbullah. He then explained this new repertoire by an analogy with the Arab uprising in Egypt: "Our movement is similar to the one on Tahrir Square in Cairo. But the difference is that here injustice is armed"31. He also gave a self-definition of his protest as intended to gather people from everywhere in Lebanon as "all regions of Lebanon are hurt" and mentioning regions that encompass all sects (Maronite, Druze, Sunni and Shiites). Al-'Asîr clearly mentioned who hurt these regions when identifying the Shi'i movement of Hizbullah naming it through its "Resistance" label to show the deviant nature of Hizbullah since its involvement alongside the Syrian regime: "You can live without bread or electricity but not without dignity. The Resistance party stole our dignity. From now on we cannot accept this anymore"32.

In a second step, later that year, another protest of al-'Asîr movement turned to a proper fight as some of his partisans were showing weapons. Hizbullah local militia hit back (or provoked) at al-'Asîr militiamen, killing two. Days after, al-'Asîr displayed bloody images on billboards showing the two faces of his partisans killed, with a Hizbullah flag tarnished with blood and including a sentence reading "Hassan Nasrallah killed Ali Samhoun in Saida" and "Hassan Nasrallah killed Lebanon". This strategy of mass communication tended to show that Hizbullah is clearly threatening the Sunni community as it killed two Sunni partisans of the Sheikh. As a consequence, this event signalled a process of militarisation of the movement that was observable early 2013 when the Sheikh al-'Asîr himself publicly appeared in a military fatigue with a rifle AK47 in his hand, during a strong protest against the presence of Hizbullah militiamen in the surroundings of his Mosque in $\mathrm{Abra}^{33}$. This image was widely spread as it was displaying a stronger and committed message to his partisans. For its part, the Lebanese 
state and namely the minister of Interior, close to 8 March ruling government, dismissed such accusations targeting Hizbullah, called for dialogue but did not intervene on the ground to disarm the al-'Asîr's militants.

A third and last step was reached later during the spring of 2013 when Sheikh al-'Asîr proclaimed a "fatwa" that was raising the Jihâd for Syria in the backdrop of the Qussayr battle that saw the Syrian Army being backed by Hizbullah members against the insurgents of the Free Syrian Army. In April, close to his Mosque in Abra, members of al'Asîr movement set up tents and carpets in the street to expand the surface for the Friday preach and huge screens to display the figure of the Sheikh delivering his speech. Following this period a new militia primarily dedicated to enrol local militants to go fighting in Syria for the cause of the Sunnis ${ }^{34}$ was publicly displayed, as an affiliate group to Sheikh al-'Asîr, under the name of "Phalanges of the Free Resistance". During the same days, Hizbullah General Secretary revealed the involvement of his militia in the Qussayr battle, alongside with Bashar el-Assad regime. In June several militiamen clearly affiliated with al-'Asîr group, armed with light weapons, took control of Saida during few hours ${ }^{35}$. Few days later, a violent clash erupted at an Army check-point near Abra killing 4 soldiers and urging the intervention of troops that dislodged and killed many al-'Asîr partisans in an extremely brutal fight of 48 hours ${ }^{36}$.

As seen above, the two movements differ by many aspects regarding the repertoire of mobilisation although they both used demonstrations and sits-in as a protest technique. The personalisation and charismatic register of al-'Asîr movement contrasts with the pluralist and democracy-oriented ASM movement. The identity of both movements in this regard is totally opposed: ASM showed a wide range of profiles among its participants in different regions of the country; the al-'Asîr movement tended to gather mainly Sunni young men of the Saida region. The fate of both movements is also revealing about their identities and structures: while the ASM transformed into several groups each of then focusing on one key-question with a perspective of changing the law, the al-'Asîr movement chose the confrontation after a radicalisation process and disappeared as a movement when Sheikh al-'Asîr vanished into thin air after the Abra battle. Tellingly, the three steps of this radicalisation process above mentioned are showing the dependency and the adaptation of Sheikh al-'Asîr regarding local and 
regional events and constraining its movement to behave more radically following the violent development in Syria. By contrast, the ASM did not seem to depend on local events and tried to avoid mingling with the polarised topic of the Syrian uprising as it finally brought political parties at the forefront of the movement, undermining the struggle for the initial claims.

\section{Conclusion}

This paper presented a comparative reading of two social movements which emerged with the beginning of the Arab uprisings in late 2010. Following a SMT approach, I proposed a relational framework with a focus on interpersonal networks allowing a better understanding of the relationships between social movements and their political environment. This perspective was divided into three lines of approach. The first, referring to contexts of emergence of social movements, showed the important differences between the beginning of the uprising process with the high hopes and expectations of ASM protesters and an enthusiasm to believe in a historical opportunity for a political change compared to the anger and resentment motivating al-'Asîr militants within a context of turmoil in Syria and the breakdown of hopes after other difficulties faced by other societies in the Arab world.

The second line focused on the social context of networks and the power relations surrounding the two social movements. It is important to note here that both faced a common sectarian context but took diametric positions towards it, combating it (ASM) or playing the sectarian card even more firmly (al-'Asîr). Means to mobilise thus refer to a vision of the world, with ASM identifying the State as the main target for its radical project of change (secularisation) and al-'Asîr's movement identifying Hizbullah as the figure of the main threat. Their mobilisations were both rooted in previous experience and trajectories within the realm of politics they were already dealing with during the previous decade. For both of them, the use of social medias helped to recruit new militants but then the main difference appeared as the ASM worked as a democratic forum and al-'Asîr's mobilisation was gathering around the figure and the speeches/preaches of its Sheikh. 
The third line underlined the consequence of this completely different manner to envision politics through the analysis of their protest actions, speeches, slogans or behaviours, the repertoires. While the ASM finally dissolved its movement once the initial process of bringing the subject of secularisation of the state at the agenda of political actors of the system had been completed and spread its forces in several specific topics, al-'Asîr radicalised to the ultimate point of violence and ended in a brutal clash with the Army probably due to Hizbullah's intention to erase this movement as a dangerous catalyst of anger towards the Shi'a. While both were radicals, their repertoires of mobilisation revealed an opposite strategy of communication based on an elitist trend for ASM and a populist manner to deal with partisans for al-'Asîr. In sum, the two movements are depicting an evolution of the Lebanese society and its political system when facing popular uprisings in a distant vs close neighbourhood.

\footnotetext{
${ }^{1}$ Joel Beinin and Frédéric Vairel (Eds), Social Movements, Mobilization, and Contestation in the Middle East and North Africa (Stanford: Stanford University Press, 2013).

2 Marc Lynch, The Arab Uprising: The Unfinished revolutions in the Middle East (New York: Public Affairs, 2013).

${ }^{3}$ Charles Tripp, The Power of the People. Paths of Resistance in the Middle East (Cambridge: Cambridge University Press, 2013)

${ }^{4}$ Amin Allal and Thomas Pierret, Au coeur des révoltes arabes. Devenir révolutionnaires (Paris: Armand Colin/Recherches, 2013).

${ }^{5}$ Laurent Bonnefoy and Myriam Catusse, Jeunesses arabes. Du Maroc au Yémen: loisirs, cultures et politiques (Paris: La Découverte, 2013).

${ }^{6}$ Paul Kingston, "Patrons, Clients and Civil Society: A Case Study in Environmental Politics in Postwar Lebanon", Arab Study Quarterly, 22 (4): 1-18 (2000).

${ }^{7}$ Agnès Favier (ed), "Municipalités et pouvoirs locaux au Liban”, Les Cahiers du CERMOC, 24. (Beirut: CERMOC, 2001).

${ }^{8}$ Karam Karam, Le mouvement civil au Liban. Revendications, protestations et mobilisations associatives dans l'après-guerre (Paris: Karthala-IREMAM, 2006).

${ }^{9}$ See for instance International Crisis Group (ICG), A Precarious Balancing Act: Lebanon and the Syrian Conflict, The Middle East Report 132 (Brussels, 2012); International Crisis Group (ICG), Too Close for Comfort. Syrians in Lebanon, The Middle East Report 141 (Brussels, 2013); International Crisis group (ICG), Lebanon's Hizbollah Turns Eastward to Syria, Middle East Report 153 (Brussels, 2014).

10 Samir Kassir, Liban: un printemps inachevé (Paris: Actes Sud, 2006).

11 Daniel Meier, The Effect of Arab Spring and Syrian Uprising on Lebanon, « Papers on Lebanon » (Oxford: Centre for Lebanese Studies, 2013). Available at: http://lebanesestudies.com/papers/papers-on-lebanon/ Accessed 7 October 2014.

12 Doug McAdam, Sydney Tarrow and Charles Tilly, Dynamics of Contention (Cambridge: Cambridge University Press, 2001).

13 Beinin and Vairel, Social Movements, Mobilization, and Contestation in the Middle East and North Africa. 14Johanna Siméant, "La violence d'un repertoire. Les sans-papiers en grève de la faim", Cultures \& Conflits 9-10 (1993). Available at: http://conflits.revues.org/218 Accessed 2 February 2014.

15 Sofia Saadeh, "Basic Issues Concerning The Personal Status Laws in Lebanon”, in Thomas Scheffler Ed., Religion, Between Violence and Reconciliation (Beirut: Ergon, 2002), 449-456.

${ }^{16}$ Allal and Pierret, $A u$ coeur des révoltes arabes.

${ }^{17}$ Against this inaction, their claims targeted the sectarianism of the political system, its corruption and call for social justice.
} 
${ }^{18}$ Romain Caillet, "Le phénomène Ahmad al-Asîr: le nouveau visage du salafisme au Liban? (1/2)". Les Carnets de l'Ifpo (2012) Available at: http://ifpo.hypotheses.org/3075 Accessed 12 September 2014.

${ }^{19}$ In arresting Syrian opponents of the regime of Bashar al-Asad and bringing them back to Syria. See Daniel Meier and Giacomo Galeno, «Le Liban au miroir du 'printemps arabe' : anciens pouvoirs et nouveaux paradigmes », in J. Chapuis (dir.), Le Moyen-Orient en marche. Perspectives croisées, Les Cahiers du CCMO, (Paris: Editions du Cygne, 2012), 67-82.

${ }^{20}$ James Scott, Weapons of the Weak: Everyday Forms of Peasant Resistance (New York: Yale University Press, 1985).

${ }^{21}$ Respectively leader of the Progressist Socialist Party, the prominent druze movement and co-founder of the 14 March coalition and leader of the Future Movement since the death of his father, former Prime minister Rafic el-Hariri assassinated on 14 February 2005.

${ }^{22}$ Cited in Romain Caillet, "Le phénomène Ahmad al-'Asîr: le nouveau visage du salafisme au Liban? (2/2)". Les Carnets de l'Ifpo (2012). Available at: http://ifpo.hypotheses.org/3240 Accessed 12 September 2014.

${ }^{23}$ Ibid.

${ }^{24}$ Non Sunni communities in Islam have long been perceived as deviant ones from the perspective of the Sunnis. Thus Alawites as well as Shia were received stigmatising labellings respectively as « nosayris » and «metwalis ». Sabrina Mervin, Histoire de l'Islam : fondements et doctrines (Paris : Flammarion, 2000). ${ }^{25}$ See The Daily Star, 20 March 2011.

${ }^{26}$ See The Daily Star, 27 February 2012

${ }^{27}$ See www.nowlebanon.com, 6 May 2012

${ }^{28}$ See www.nowlebanon.com, 13 May 2012

${ }^{29}$ Antoine Messarra, "Les parties politiques au Liban. Une expérience arabe pionnière et en déclin", Revue d'Etudes du Monde Musulman et de la Méditerranée, 81-82 (3-4): 135-151 (1996).

30 Caillet, "Le phénomène Ahmad al-'Asîr (2/2)"

${ }^{31}$ See L'Orient le Jour, 29 June 2012.

32 Ibid.

${ }^{33}$ See L'Orient le Jour, 23 February 2013.

${ }^{34}$ See L'Orient le Jour, 28 April 2013.

${ }^{35}$ See Al-Akhbar, 20 April 2013.

${ }^{36}$ During which the Lebanese Army finally lost 16 troops. See L'Orient le Jour, 25 June 2013. Interestingly, no precise death toll or number of injured people was disclosed among the partisans of the Sheikh. The state muteness towards the final episode of Sheikh al-'Asîr could be linked to Hizbullah's involvement in this assault and the secrecy the party of God tends to favour in such security issues. 